\title{
AN INEQUALITY FOR THE ANALYSIS OF VARIANCE
}

\author{
Norbert Kaiblinger And Bernhard SpAngL
}

Abstract. We prove a generalization to matrices and tensors of the Szôkefalvi-Nagy inequality and the Grüss-Popoviciu inequality. Our more general version is required in the analysis of variance (ANOVA).

Mathematics subject classification (2010): 15A45, 26D15, 47A30, 51M16, 52A40, 60E15, 62J10.

Keywords and phrases: Szókefalvi-Nagy inequality, Grüss-Popoviciu inequality, Hankel matrix, ANOVA, discrete Fourier transform.

\section{REFERENCES}

[1] G. Alpargu and G. P. H. Styan, Some comments and a bibliography on the Frucht-Kantorovich and Wielandt inequalities, Innovations in Multivariate Statistical Analysis, Springer, 2000, pp. 1-38.

[2] R. Bhatia And C. Davis, A better bound on the variance, Amer. Math. Monthly 107, 4 (2000), 353-357.

[3] M. Biernacki, H. Pidek And C. Ryll-Nardzewski, Sur une inégalité entre des intégrales définies, Ann. Univ. Mariae Curie-Skłodowska. Sect. A 4 (1950), 1-4. (French, with Polish summary)

[4] A. Brauer And A. C. Mewborn, The greatest distance between two characteristic roots of a matrix, Duke Math. J. 26 (1959), 653-661.

[5] J. Fox, Applied Regression Analysis and Generalized Linear Models, SAGE Publ., 2015.

[6] G. GRÜSS, Über das Maximum des absoluten Betrages von $\frac{1}{b-a} \int_{a}^{b} f(x) g(x) d x-\frac{1}{(b-a)^{2}} \int_{a}^{b} f(x) d x$ $\int_{a}^{b} g(x) d x$, Math. Z.39, 1 (1935), 215-226. (German)

[7] I. Gutman, K. Ch. Das, B. Furtula, E. Milovanović and I. Milovanović, Generalizations of Szókefalvi Nagy and Chebyshev inequalities with applications in spectral graph theory, Appl. Math. Comput. 313 (2017), 235-244.

[8] S. T. Jensen AND G. P. H. STYAn, Some comments and a bibliography on the Laguerre-Samuelson inequality with extensions and applications in statistics and matrix theory, Analytic and Geometric Inequalities and Applications, Kluwer Acad. Publ., 1999, pp. 151-181.

[9] D. S. Mitrinović, J. E. PeČArić And A. M. Fink, Classical and New Inequalities in Analysis, Kluwer Acad. Publ., 1993.

[10] C. P. Niculescu AND L.-E. Persson, Convex Functions and Their Applications, Springer, 2018.

[11] T. Popoviciu, Sur les équations algébriques ayant toutes leurs racines réelles, Mathematica (Cluj) 9 (1935), 129-145. (French)

[12] D. Rasch, J. Pilz, R. Verdooren and A. Gebhardt, Optimal Experimental Design With R, CRC Press, 2011.

[13] D. Rasch and D. Schott, Mathematical Statistics, Wiley, 2018.

[14] D. Rasch, R. Verdooren And J. PIlz, Applied Statistics, Wiley, 2020.

[15] H. SChEFFÉ, The Analysis of Variance, Wiley, 1959.

[16] S. R. Searle AND M. H. J. Gruber, Linear Models, 2nd ed., Wiley, 2017.

[17] R. ShARMA, M. GUPTA AND G. KAPOOR, Some better bounds on the variance with applications, J. Math. Inequal. 4, 3 (2010), 355-363.

[18] G. SzŐKEFALVI-NAGY, Über algebraische Gleichungen mit lauter reellen Wurzeln, Jahresber. Dtsch. Math.-Ver. 27 (1918), 37-43. (German)

[19] B. Spangl, N. Kaiblinger, P. RUCKdeschel And D. Rasch, Minimal sample size in balanced ANOVA models of crossed, nested and mixed classifications, preprint, Arxiv 1910.02722. 